\title{
Vulgar Imagery and Biological Themes: An Analysis of the Nazis' Anti-Semitic Dialogue
}

\author{
Thomas Brown
}

Department of History, University of Alberta, Edmonton, Alberta

Department of Political Science, University of Alberta, Edmonton, Alberta

Corresponding author: tbrown2@ualberta.ca

\section{ABSTRACT}

During World War Two, the Nazi regime created a mechanized and systematic killing process with the intention of eliminating the "undesirables" of their occupied territory-now referred to as the Holocaust. While the true scale of this system was not openly publicized at the time, the motivation for its existence was an entrenched element of the Nazi ideology-the creation of a racially pure German state. The question stands as to how a political party could bring a nation in line with an ideology predicated on racism, ethnonationalism and the destruction of an entire people? This paper will provide an analysis of the type of language the Nazis used to do exactly that. Through studying their vocabulary, we find that their persistent use of biological themes and metaphors supported their self-defined "scientific anti-Semitism" and we can follow the effect this had on the general public. The Nazis were not the first group to push a violently discriminatory agenda upon their general population nor were they the last. By analyzing how they spoke on the topic we can see patterns and general themes emerge, giving us the ability to spot them in contemporary examples and helping us identify the emergence of dangerous movements before they take control.

"We have exterminated a bacterium because we do not want in the end to be infected by the bacterium and die of it. I will not see so much as a small area of sepsis appear here or gain a hold. Wherever it may form we will cauterize it."1 These are the words of Reichsführer of the SS Heinrich Himmler, spoken on October 4, 1943, while addressing a group of SS officers. The "bacterium" in question was the Jewish people; the "cauterization" was their genocide. Although certainly not everyone in Nazi-controlled territory referred to the Jewish people in such a way, by 1943, Nazi dialogue surrounding the "Jewish Question"-a term used to characterize debate on the appropriate treatment of the Jewish people ${ }^{2}-$ had thoroughly adopted this type of vocabulary. While antiSemitism and German nationalism both existed long before the rise of the Nazi Party, it is through this sort of science-based, emotive language that they forged a tailored and well-defined brand of anti-Semitic propaganda. This essay will argue that the Nazis' use of these biological themes and metaphors in regard to the Jewish people and German racial superiority can help us understand the core beliefs of their anti-Semitic views. It will then go on to explain how these themes and their 
portrayal in propaganda helped build support for the Nazi's treatment of the Jews. While such language permeated all levels of Nazi dialogue, this essay will focus on its use from high ranking officials and in their general propaganda material. These two key examples illustrate the mindset of Nazi policy-makers and its effect on those targeted by their propaganda efforts, which included both soldiers and civilians.

The earliest accounts of anti-Semitism and the persecution of the Jewish people in Europe can be traced back centuries. Since the emergence of the first Jewish diaspora in the eighth century $B C E$, the Jewish people have faced much aggression from various host countries. As this trend continued into the nineteenth and twentieth centuries, the Jewish people went on to face varying degrees of persecution or acceptance. In the Weimar Republic era in Germany (191833) following the First World War, anti-Semitism began taking on many forms which varied in approach and intensity. Many liberals for instance saw any problems that people had with the Jewish religion specifically being practiced in Germany as irrational. ${ }^{3}$ However, evidence also shows that some German liberals had concerns with any religious traditions being practiced in Germany, which they saw as supporting values that could undermine their universalist (a concept that stresses a particular value as being universally applicable) approach to liberal values. ${ }^{4}$

Within the realm of Weimar political parties, center-right and religious groups such as the Zentrum, who ran in part on a Christian platform upholding German cultural values, supported the need for Jews to assimilate into German culture. ${ }^{5}$ However anti-Semitism did not play a pivotal role in defining any of these parties' overarching principles. By the late 1920s, this would not be the case for the Nazis. Written during his time in prison, Adolf Hitler explains in his book Mein Kampf how he came to his "spiritual awakening" in Vienna, when he began to question the Jewish people and their relationship to Germany. ${ }^{6}$ Upon his release in December 1924, Hitler quickly took command of the Nazi Party by centralizing power in himself and guiding it both politically and ideologically, enabling him to better define and promote the party's anti-Semitic views. ${ }^{7}$

In his book, Nazi Anti-Semitism: From Prejudice to the Holocaust, Swiss historian Philippe Burrin characterizes Nazi ideology as embodying all three general types of anti-Semitism that existed in early twentieth century Europe. The Nazis were religiously anti-Semitic, claiming the Jewish people to be religiously and culturally separate from the German people; nationally anti-Semitic, claiming the Jewish people were a threat to the German nation; and racially anti-Semitic, seeing the Jewish race as being apart from and inferior to that of the Germans. ${ }^{8}$ The Nazis' framing of the Jewish people in this way, although not entirely unique to its time, was quintessential to their ideology and to Hitler's world view. By defining the Jews as fundamentally incompatible with the German people, the Nazi doctrine completely rejected any possibility of assimilation. Furthermore, it is important to recognize when analyzing the language they used in regard to the Jewish people that the Nazis saw them as being racially inferior to the German people. However more pressingly, the Jews were the pinnacle group that could undermine their vision of a greater German nation; they saw the Jews as simultaneously supporting foreign capitalists that threatened German workers, and a Bolshevik class conflict that could fracture their idea of a united Volk (a term used to refer to the idea of a nationally-defined German people or community). ${ }^{9}$

The lack of tolerance or desire to incorporate the Jewish people into their vision of Germany was therefore a major element of Nazi ideology. This idea was encapsulated in the aforementioned Mein Kampf. Seeing the world as in constant struggle with only the strong being able to thrive, Hitler reaffirms German racial superiority and the need to fight, predicated on Germany existing in a Social Darwinist 
environment. By viewing the world as in constant struggle between ethnic nation-states, Hitler explains two key problems he has with the Jewish people: their stateless nature and the damage they were causing from within the German polity.

No, the Jew is no nomad; for the nomad had also a definite attitude towards the concept of work which could serve as a basis for his later development in so far as the necessary intellectual premises were present... In the Jew, however, this attitude is not at all present; for that reason he was never a nomad, but only and always a parasite in the body of other peoples. That he sometimes left his previous living space has nothing to do with his own purpose but results from the fact that from time to time he was thrown out by the host nations he had misused. His spreading is a typical phenomenon for all parasites; he always seeks a new feeding ground for his race. ${ }^{11}$

It is important to note that while this excerpt from Mein Kampf comes from the translation by James Murphy, minus grammatical differences, the use of key words is the same across other translations. ${ }^{12}$ In this extract, Hitler compares the Jewish people's history to that of the nomads, another stateless group, and in doing so provides a sample of the type of vocabulary that would become typical throughout Nazi dialogue. Words like "parasite", "host nation" and "feeding ground", all exemplify the mindset the Nazis possessed towards the Jewish people: that they represented a disease that needed to be eradicated. Countless examples of this biology-based language appear with astonishing consistency throughout the book.

The use of these biological terms illustrates the Nazi's belief that their anti-Semitism was not just values-based, but in fact scientific. Beyond just being founded upon nationalist pride, religious dogma, or political necessity, the German's racial superiority was described as a law of nature. ${ }^{13}$ It is this idea that manifests itself throughout Nazi dialogue, with the Jewish people being described using words such as parasites, rodents, bacterium and vipers; all things which connote disease, illness or blood sucking. This idea is then coupled with the notion of a German nation united by its blood. The connection being drawn here was that the German people (body) was racially superior and at risk of being harmed by the Jewish people (rats, vermin, bacteria, etc.) and that Germany needed to be aware of this fact in order to fight back. This concept was articulated in Mein Kampf, where Hitler wrote, "for racially pure people which are conscious of its blood can never be enslaved by the Jew. In this world [the Jew] will forever be master over bastards alone. And so he tries systematically to lower the racial level by a continuous poisoning of individuals." 14 The Nazis then began promoting the idea of their racial superiority by the use of biologically-themed metaphors and imagery.

A common trope found in this context is that of the German "body" being attacked or becoming ill because of the noxious Jewish "organism" or "bacterium". 15 In speaking to Himmler in 1942, Hitler was quoted as saying, "the discovery of the Jewish virus is one of the greatest revolutions that has taken place in the world... How many diseases have their origin in the Jewish virus! We shall regain our health only by eliminating the Jew."16 Adolf Eichmann, architect of the "Final Solution" (the Nazi plan to commit genocide on the Jewish people), was also quoted as using such language. In early 1941, Eichmann justified the actions of SS troops in the 1938 Anschluss (the German annexation of Austria) as an attempt to "provide [the country] with injections of Jewish solutions."17 The sheer pervasiveness of this language gives strong credence to the idea that anti-Semitism was not just an element of their speech, but part of their core ideology and required a focused and consistent effort to act upon it. Especially for high ranking Nazi officials, this "bodystate" world view moved beyond a metaphorical technique and instead "described [their] reality."18 
Now that the Jewish people had been defined not only as "the other," but also as an invasive and existential threat to Germany, the Nazis could continue with the analogy and push the idea that the only option was to treat the Jews in the same way one would treat a rodent or diseaseextermination or inoculation. Hitler's Table Talks, a collection of Hitler's transcribed conversations from 1941-44, outlines many discussions that use such terminology: "It's not a bad idea, by the way, that public rumour which attributes to us a plan to exterminate the Jews. Terror is a salutary thing." 19 These words were spoken by Hitler in 1942. Throughout this seven-hundred-page volume the historian, Hugh Trevor-Roper, shows exactly how Hitler explains his thoughts and ideas in dinner conversations. What is not surprisingconsidering this period encapsulates the years in which Nazi extermination of the Jews was at its highest-is just how willing Hitler was to accept the destruction and suffering of others to support the Nazi cause. This mindset of supporting the annihilation of the Jewish people was not exclusively adopted by the Führer either. Joseph Goebbels, Reich Minister of Propaganda, recorded these words in his diary following the Wannsee Conference of 1941-a meeting where Nazi High Command gathered under Reinhard Heydrich to organize the destruction of the Jewish people. Here, Goebbels recalls how he felt about the Nazi approach to the Jews in light of their plan: "Now the world has come to war, the destruction of the Jews must be its necessary consequence." 20

There is also evidence that through such metaphorical techniques and careful language choices it is possible to influence the attitudes of the general population. In the case of the Nazis, their vernacular could have acted to help sway the people to be more supportive of their Jewish stance. A 2011 study by a team of cognitive psychologists at Stanford University showed that metaphors, beyond being just a comparative language technique, can have "'real consequences' for how people conceptualize and solve social problems." ${ }^{21}$ In this case the "problem" for the Nazis would be the Jewish Question. The metaphors then, beyond stirring feelings of animosity towards the Jews, could have had a real cognitive effect, even on those outside Nazi High Command. Many historians since the end of the war have gone on to examine a variety of cases that demonstrate the extent to which Nazi anti-Semitic propaganda was successful in shaping German sentiment, as I will be discussing in subsequent paragraphs.

Outside of High Command, the effect of this propaganda effort was felt strongly within the Nazi war machine itself. In 2018, the University of Vienna's Johannes Steizinger published an article outlining the "dehumanizing" impact Nazi philosophy and dialogue had on SS and Wehrmacht prison guards. ${ }^{22}$ Because of how these beliefs were engaged with and held, the guards began to view their captives as subhuman, with whom they shared no common ground. ${ }^{23}$ This dehumanization is discussed in depth in The Drowned and the Saved, a written firsthand account by Auschwitz survivor, Primo Levi, of his war experience. In this book, Levi tells of the horror and torment he experienced at the hands of Nazi prison guards. Beyond simply being kept in captivity, he describes the excessive use of violence and punishment unleashed upon him as being an end in itself, not simply the means to a greater goal. He summarizes what he considers to be the motivation behind the Nazi guard's mistreatment of the Jews in this line: "The "enemy" [the Jew] must not only die, he must die in torment." ${ }^{24}$ In earlier chapters Levi explains how, based on his observations and the observations of other academics of his time, this level of hatred and disgust was greatly inspired by the ideology and propaganda that immersed the German population during the Nazi regime. ${ }^{25}$

The book What We Knew: Terror, Mass Murder and Everyday Life in Nazi Germany, by Eric Johnson and Karl-Heinz Reuband also presents a collection of firsthand accounts, in this case attesting to 
the effect Nazi anti-Semitic dialogue had on the German population. ${ }^{26}$ These testimonials came from individuals in various parts of German society; this included soldiers, workers, priests and the Jewish people themselves. One account shows the experience of a Catholic from Cologne who was a member of the Hitler Youth during the war. He explains how the reality that Nazi propaganda described seemed "very plausible," 27 going on to tell of how he felt increasingly inclined join the Nazis and subscribe to their anti-Semitic beliefs. While the other accounts provide a range of attitudes towards the Jewish people, the resounding sentiment from this work is that antiSemitism existed to varying degrees in Germany prior to the Nazis taking control. However, once they took power, the Nazis catalyzed pre-existing Jewish hatred. Based on survey information collected during their research effort, Johnson and Reuband show that relationships between the Jews and Germans deteriorated during the Nazi reign. They explain, "Over two thirds of [Jewish] families before 1933 had friendly relations with non-Jews in their communities, after 1933 nearly two-thirds had relations that the survivors described as clearly worse or even hostile." ${ }^{28}$

How biological themes specifically were used to generate this effect is outlined in a paper by Sarah Anne Fisk titled, "When Words Take Lives: The Role of Language in the Dehumanization and Devastation of Jews in the Holocaust." For instance, she provides one example focusing on the comparison of the Jews to rats. To do this, Fisk draws on a selection of other historians' works and primary sources, such as the infamous propaganda film, Der Ewige Jude (The Eternal Jew). She then shows how the comparison of the Jews to rats in particular draws on the idea pushed by the Nazis that they were disease ridden, existing in "swarms" wherever they went. ${ }^{30}$ The effect of this can be seen in reports that show German soldiers bragging about the number of Jews they were able to kill in one day, all the while using this biological language. ${ }^{31}$ The idea of the
Jews being some sort of pest was also shown to have helped generate support for the "the logistical need to remove" the Jewish people from society; even if the Germans supporting this idea were not entirely morally convinced, they saw it as necessary. ${ }^{32}$ Many more cases are then examined, looking at the use of imagery surrounding vipers, ${ }^{33}$ vermin, ${ }^{34}$ and serpents. ${ }^{35}$ By looking at the dialogue used in each of these cases, a pattern emerges of an acceptance among Germans of Nazi policy towards the Jews. This acceptance was predicated in a significant way on the Nazi use of this language to push a world view that dehumanized the Jewish people.

By analyzing different Nazi media types, historian George Mosse has shown the powerful effect popular culture has on shaping public sentiment, especially in the context of German anti-Semitism. ${ }^{36}$ In looking at popular culture, we not only uncover how the Jewish "image" was portrayed but also how it was embraced. ${ }^{37}$ American historian Jeffrey Herf presents an example of this in a 2005 article examining the Nazi propaganda publication, Das Reich, which frequently warned the German people of the "parasitic danger of this [Jewish] race." $38 \mathrm{He}$ then shows how from 1940 to 1944, sales of this journal went from 500,000 to $1,400,000$. With consumption rates going up nearly threefold, we can see a continuing pattern of German willingness to consume and embrace Nazi propaganda, laden with anti-Semitic rhetoric of a biological nature.

Mosse also discusses how this sort of antiSemitic propaganda consumed in popular culture was effective in helping to mobilize the German population. He argues that as Hitler successfully gave their anti-Semitism political relevance by tying it to a political issue, he created a platform that could be advocated for and acted upon: Mosse here is expanding on an argument laid out in the works of Hannah Arendt. ${ }^{39}$ Therefore, the use of biologically-based themes in popular culture helped influence a range of 
media types that were regularly consumed by the German public, increasing their exposure to and acceptance of Nazi Jewish policy.

An example of this can be found in the children's book, The Poisonous Mushroom, written by Ernst Hiemer, a writer who worked extensively throughout the war publishing anti-Semitic content. In this book, first published in 1938, Hiemer tells the story of a young German girl who needs to go to see the local doctor, an old Jewish man. Once she arrives at his office, the young girl hears screams, and the doctor is described as emerging from the room once the screams fell silent:

Inge looks up. The Jew appears. Terrified she jumps up. Her eyes stare into the face of the Jewish doctor. And this face is the face of the Devil. In the middle of the Devil's face sits a huge bent nose. Behind glasses glitter two criminal eyes. And a sneer plays on the bulging lips... Before the Jew can grasp her, she hits the Jewish doctor in his fat face with her hand. ${ }^{40}$

Aimed at children, the book was written in simple sentences but with very carefully chosen vocabulary. Not unlike the more advanced language used in literature aimed at adults, phrases like "the Devil's face", "criminal eyes" and "bulging lips" were meant to elicit the same emotions of disgust and resentment in children as parasite and bacterium would for adults. As the war continued, the overt anti-Semitism in Hiemer's writing escalated. In 1940, he published a book which, translated into English, is The PoodlePug-Dachshund-Pinscher and other contemplative stories. In Hiemer's book we find a collection of short stories all focused around the theme of comparing the Jewish people to different animals. Each chapter title of this book names a particular animal that represents the Jews and then goes into great detail explaining how the comparison holds. Each of these; "The Tapeworm", "The Poisonous Serpent", "The Bacterium"41, all precisely fit the type of language the Nazis pushed.

Targeting an adult audience, another example of anti-Semitic propaganda can be found in German films released during the Nazi regime. Relative to other industries in Germany and especially relative to other forms of art, the film industry remained fairly autonomous throughout WWII. Although the central Berlin Propaganda Ministry had the ultimate say as to whether a film was allowed to be released, the Nazis exercised very little control over the production process itself and only guided the demand for content. ${ }^{42}$ In these films, most of which were released between 1940-41, we find the same stereotypes, tropes, and biological themes as in other media types. ${ }^{43}$ One of the most infamous examples of Nazi propaganda in this form was the aforementioned 1940 film, Der Ewige Jude. Featuring many shots from Polish ghettos, one of the main aims of the film was to show the German public the Jewish people in their "original state," before they, "put on the mask of civilized Europeans. ${ }^{\text {"44 }}$ Nazi propaganda reviewers commended the honesty of the film for showing "the Jew [as] an oriental barbarian who has insinuated himself cleverly into European society, and now exploits it parasitically." 45 From this example we can see even institutions more loosely controlled by the Nazis were affected by their anti-Semitic propaganda, and as such helped it be consumed and embraced by a wider German audience. ${ }^{46}$ This would help create an even greater sense of immersion in anti-Semitic language for the German people, adding to the effectiveness of their message.

As we can see, from quiet words uttered in dinner conversations to slogans bellowed over megaphones at rallies, the type of language the Nazis adopted to address the Jewish Question was a trademark feature of their propaganda. When reading the works of any of the top officials, be it Hitler, Himmler, or Goebbels, it is nearly impossible not to notice the aggression and persistence with which they extol their anti-Semitic views. 
These views, although hard to reconcile from the perspective of a modern liberal democracy, played an enormous role in shaping some of the most catastrophic events of the twentieth century. Utilizing language techniques such as biological metaphors to raise the "blood consciousness" of the German people, the Nazis managed to rally a nation around an ideology in part predicated on the destruction of an entire race. While this particular chapter of history has come to a close, understanding the methods the Nazis used to gain the support they did can now be used to help us understand similar ideologically driven and hateful movements in contemporary examples. It was not the first time a nation has gathered behind such a cause-it was certainly not the last-but by learning to identify the key elements of these movements perhaps we can learn to stop them before they have a chance to rise, thereby avoiding the destructive power they possess. 


\section{Notes}

1. Manus I. Midlarsky, Origins of Political Extremism: Mass Violence in the Twentieth Century and Beyond (Cambridge University Press, 2011), 102.

2. Lawrence Stepelevich, "Max Stirner and The Jewish Question," Modern Judaism: A Journal of Jewish Ideas \& Experience 34, no. 1 (2014): 43, https://doi.org/10.1093/mj/kjt021.

3. Neil Gregor, How to Read Hitler (London: Granta, 2005), 118.

4. Gregor, How to Read Hitler, 62.

5. Thomas Childers, The Nazi Voter: The Social Foundations of Fascism in Germany, 1919-1933 (Chapel Hill: University of North Carolina Press, 2010), 367.

6. Adolf Hitler, Mein Kampf. trans. James Murphy (London: Hurst and Blackett, 1939), 384.

7. Petre Zoltán, "Adolf Hitler and the NSDAP's Political Discourse between 1920-1933," Astra Salvensis 2, no. 3 (2014): 103, Central and Eastern European Online Library.

8. Philippe Burrin, Nazi Anti-Semitism: From Prejudice to the Holocaust, trans. Janet Lloyd (New York: The New Press, 2004), 154.

9. Childers, The Nazi Voter, 367.

10. Hitler, Mein Kampf, 240.

11. Hitler, Mein Kampf, 255-256.

12. Adolf Hitler, Mein Kampf, trans. Ralph Manheim (Boston: Houghton Mifflin, 1943), 694.

13. Adolf Hitler, Mein Kampf, trans. James Murphy (London: Hurst and Blackett, 1939), 142.

14. Hitler, Mein Kampf, 207.

15. Hitler, Mein Kampf, 305.

16. Michael Burleigh and Wolfgang Wippermann, The Racial State: Germany 1933-1945 (Cambridge: Cambridge University Press, 1991), 158.

17. Bettina Stangneth, Eichmann Before Jerusalem: The Unexamined Life of a Mass Murderer (New York: Alfred A. Knopf, 2014), 181.

18. Andreas Musolff, "What Role Do Metaphors Play in Racial Prejudice? The Function of AntiSemitic Imagery in Hitler's Mein Kampf," Patterns of Prejudice 44, no. 1 (2007): 21, https://doi. org/10.1080/00313220601118744.

19. Adolf Hitler, H. R Trevor-Roper, and Martin Bormann, Hitler's Table Talks, 1941-1944 (Oxford: Oxford University Press, 1988), 87.

20. Florent Brayard, "To Be Exterminated as Partisans: On a Note by Himmler," POLITIX 21, no. 82 (2008):

12, https://doi.org/10.3917/pox.082.0009.

21. Paul H. Thibodeau and Lera Boroditsky, "Metaphors We Think With: The Role of Metaphor in Reasoning," PLOS ONE 6, no. 2 (2011): 1, https://doi.org/10.1371/journal.pone.0016782.

22. Johannes Steizinger, "The Significance of Dehumanization: Nazi Ideology and Its Psychological Consequences," Politics, Religion \& Ideology 19, no. 2 (2018): 152, https://doi.org/10.1080/21567689.2018 .1425144 .

23. Steizinger, "The Significance of Dehumanization," 155.

24. Primo Levi, The Drowned and the Saved, trans. Raymond Rosenthal (New York: Vintage International, 1989), 120.

25. Levi, The Drowned and the Saved, 23-35.

26. Eric A. Johnson and Karl-Heinz Reuband, What We Knew: Terror, Mass Murder, and Everyday Life in Nazi Germany (New York: Basic Books, 2005), 434, EBSCOhost eBook Collection.

27. Johnson and Reuban, What We Knew, 163. 
28. Johnson and Reuband, What We Knew, 273-274.

29. Sara Anne Fisk, "When Words Take Lives: The Role of Language in the Dehumanization and Devastation of Jews in the Holocaust," (MA diss., University of Canterbury, 2009), University of Canterbury Research Repository, (https://hdl.handle.net/10092/2900).

30. Fisk, "When Words Take Lives," 79-80.

31. Fisk, "When Words Take Lives," 79-80.

32. Fisk, "When Words Take Lives," 81.

33. Fisk, "When Words Take Lives," 86.

34. Fisk, "When Words Take Lives," 25.

35. Fisk, "When Words Take Lives," 51.

36. George L. Mosse, "The Image of the Jew in German Popular Culture, Felix Dahn and Gustav Freytag,"

The Leo Baeck Institute Yearbook 2, no. 1 (1957): 218, https://doi.org/10.1093/leobaeck/2.1.218.

37. Mosse, "The Image of the Jew," 218.

38. Jeffrey Herf, "The 'Jewish War': Goebbels and the Antisemitic Campaigns of the Nazi Propaganda Ministry," Holocaust and Genocide Studies 19, no. 1 (2005): 60, https://doi.org/10.1093/hgs/dci003.

39. Mosse, "The Image of the Jew," 227.

40. Steve Hochstadt, Sources of the Holocaust (Basingstoke, Hampshire: Palgrave Macmillan, 2004$), 319$.

41. Ernst Heimer, Der Pudelmopsdackelpinscher (Nuremberg: Der Sturmer-Buchverlag, 1940).

42. Richard Geehr, John Heineman, and Gerald Herman, "Wien 1910: An Example of Nazi Anti-Semitism," Film \& History 15, no. 3 (1985): 53, ProQuest.

43. Geehr, Heineman, and Herman, “Wien 1910," 53.

44. Unser Wille und Weg, 10 (1940): 54-55, https://research.calvin.edu/german-propaganda-archive/ ewig.htm.

45. Richard Taylor, Film Propaganda: Soviet Russia and Nazi Germany (London: I. B. Tauris: 1998$), 175$.

46. Taylor, Film Propaganda, 175. 


\section{Bibliography}

Brayard, Florent. "'To Be Exterminated as Partisans': On a Note by Himmler." POLITIX 21, no. 82 (2008): 9-37.

Burleigh, Michael and Wolfgang Wippermann. The Racial State: Germany 1933-1945. Cambridge: Cambridge University Press, 1991.

Burrin, Philippe. Nazi Anti-Semitism: From Prejudice to the Holocaust. Translated by Janet Lloyd. New York: The New Press, 2004.

Childers, Thomas. The Nazi Voter: The Social Foundations of Fascism in Germany, 1919-1933. Chapel Hill: University of North Carolina Press, 2010.

Fisk, Sara Anne. "When Words Take Lives: The Role of Language in the Dehumanization and Devastation of Jews in the Holocaust." MA diss., University of Canterbury, 2009. University of Canterbury Research Repository (https://hdl.handle.net/10092/2900).

Geehr, Richard, John Heineman, and Gerald Herman. "Wien 1910: An Example of Nazi Anti-Semitism.” Film \& History 15, no. 3 (1985): 50-64. ProQuest.

Gregor, Neil. How to Read Hitler. London: Granta, 2005.

Heimer, Ernst. Der Pudelmopsdackelpinscher. Nuremberg: Der Sturmer-Buchverlag, 1940.

Herf, Jeffrey. "The 'Jewish War': Goebbels and the Antisemitic Campaigns of the Nazi Propaganda Ministry." Holocaust and Genocide Studies 19, no. 1 (2005): 51-80. https://doi.org/10.1093/hgs/ dci003.

Hitler, Adolf. Mein Kampf. Translated by James Murphy. London: Hurst and Blackett, 1939.

Hitler, Adolf. Mein Kampf. Translated by Ralph Manheim. Boston: Houghton Mifflin, 1943.

Hitler, Adolf, Hugh Trevor-Roper, and Martin Bormann. Hitler's Table Talks, 1941-1944. Oxford: Oxford University Press, 1988.

Hochstadt, Steve. Sources of the Holocaust. Basingstoke, Hampshire: Palgrave Macmillan, 2004.

Johnson, Eric A. and Karl-Heinz Reuband. What We Knew: Terror, Mass Murder, and Everyday Life in Nazi Germany. New York: Basic Books, 2005. EBSCOhost eBook Collection.

Levi, Primo, The Drowned and the Saved. Translated by Raymond Rosenthal. New York: Vintage International, 1989

Midlarsky, Manus I. Origins of Political Extremism: Mass Violence in the Twentieth Century and Beyond. Cambridge: Cambridge University Press, 2011.

Mosse, George L. "The Image of the Jew in German Popular Culture, Felix Dahn and Gustav Freytag." The Leo Baeck Institute Yearbook 2, no. 1 (1957): 218-227. https://doi.org/10.1093/leobaeck/2.1.218.

Musolff, Andreas. "What Role Do Metaphors Play in Racial Prejudice? The Function of Anti-Semitic Imagery in Hitler's Mein Kampf." Patterns of Prejudice 41, no. 1 (2007): 21-43. https://doi. org/10.1080/00313220601118744.

Petre, Zoltán. "Adolf Hitler and the NSDAP's Political Discourse Between 1920-1933." Astra Salvensis 2, no. 3 (2014): 99-105. Central and Eastern European Online Library.

Stangneth, Bettina. Eichmann Before Jerusalem: The Unexamined Life of a Mass Murderer. New York: Alfred A. Knopf, 2014.

Steizinger, Johannes. "The Significance of Dehumanization: Nazi Ideology and Its Psychological Consequences." Politics, Religion \& Ideology 19, no. 2 (2018): 139-57. https://doi.org/10.1080/21 567689.2018.1425144.

Stepelevich, Lawrence. "Max Stirner and The Jewish Question." Modern Judaism: A Journal of Jewish Ideas \& Experience 34, no. 1 (2014): 42-59. https://doi.org/10.1093/mj/kjt021. 
Taylor, Richard. Film Propaganda: Soviet Russia and Nazi Germany. London: I. B. Tauris, 1998.

Thibodeau, Paul H. and Lera Boroditsky. "Metaphors We Think With: The Role of Metaphor in Reasoning." PLOS ONE 6, no. 2 (2011). https://doi.org/10.1371/journal.pone.0016782.

Unser Wille und Weg, 10 (1940): 54-55. https://research.calvin.edu/german-propaganda-archive/ewig. htm. 